\title{
Peran American Military Industrial Complex dalam Konflik Bersenjata di Timur Tengah
}

\author{
Ajie Mahar Muhammad \\ UniversitasDiponegoro \\ email: ajiemahar0@gmail.com
}

\begin{abstract}
The Middle East countries, such as Iran, Iraq, Lebanon, Syria, Yemen, Bahrain, Egypt, Turkey, or other countries, seemed to endlessly suffered security and political conflicts. In some countries, the conflict even leads to armed fightings, for example in Iraq, Syria and Yemen. Every day, the medias broadcast the development of the armed conflict in the Middle East, as if telling that this conflict is going to last forever. This phenomenon raises a question, what causes the Middle Eastern conflict to be prolonged? This article addresses the relations between the conflict and the phenomenon of neoliberalism which becomes the main driver of global economy. Using the concept of Military-Industrial Complex, this article argues that there are giant capitalist actors who maintain this condition so they can get huge profits due to the long-drawn armed conflict.
\end{abstract}

Keywords: Middle East, armed conflict, neoliberalism, military-industrial complex

\section{Abstrak}

Negara-negara di kawasan Timur Tengah, mulai dari Iran, Irak, Lebanon, Suriah, Yaman, Bahrain, Mesir, hingga Turki, dan negara-negara lainnya, seolah tak henti didera konflik politik. Di beberapa negara, konflik bahkan berujung pada konflik bersenjata, misalnya di Irak, Suriah dan Yaman. Setiap harinya, selalu muncul berita yang mengabarkan perkembangan konflik bersenjata di kawasan tersebut, seakan menunjukkan bahwa konflik di sana tak akan pernah usai. Hal tersebut memunculkan pertanyaan, apa yang menyebabkan konflik di Timur Tengah berlarut-larut? Artikel ini mengaitkan hubungan antara konflik bersenjata yang terjadi di Timur Tengah dengan fenomena neoliberalisme yang 
saat ini menjadi motor penggerak ekonomi global. Dengan menggunakan konsep military-industrial complex, artikel ini berargumen bahwasanya ada pemodal besar yang memaksa kondisi ini untuk tetap berlangsung karena mereka diuntungkan oleh berlarut-larutnya perang ini.

Kata Kunci: Timur Tengah, konflik bersenjata, neoliberalisme, military-industrial complex

\section{Pengantar}

Konflik bersenjata merupakan suatu fenomena yang mengancam perlindungan terhadap Hak Asasi Manusia karena para penduduk sipil dalam suatu wilayah konflik akan mengalami ancaman nyawa, fisik, dan psikologis. Fenomena ini dapat disaksikan di kawasan Timur Tengah yang menjadi medan pertempuran antara berbagai faksi, terutama antara negara dengan kelompok-kelompok pemberontak yang tidak puas dengan kinerja pemerintah'. Situasi ini memaksa para penduduk sipil untuk meninggalkan tanah kelahirannya dan menjadi pengungsi (refugee) maupun pencari suaka (asylum seeker)².

Menurut International Organization for Migration (IOM), sepertiga dari keseluruhan imigran di dunia merupakan mereka yang berkebangsaan Middle East and North Africa (MENA)3. Jumlah pengungsi yang berasal dari negara-negara tersebut setiap tahunnya menunjukkan kenaikan yang sangat signifikan. Hal itu dapat kita saksikan melalui grafik di bawah ini.

\section{Gambar 1: Grafik Migrasi internasional di Timur Tengah dan Afrika Utara sejak tahun 1990 hingga 2015}

Dalam grafik tersebut terlihat bahwa peningkatan jumlah migran yang signifikan mulai terjadi tahun 2010, dimana jumlah migran dari Timur Tengah dan Afrika Utara mencapai 28 juta jiwa. Angka tersebut merupakan dua kali

1 Zaman, Shamsuz. 2015. "Rise of the Non-State Actors in Middle East: Regional Dimension". IPRI Journal. Vol. XV No. 1:51-65.

2 Asylum Seeker adalah mereka yang mencari perlindungan internasional namun status refugee belumditentukan. Sedangkan refugee adalah para Asylum seeker yang telah memperoleh status 'pengungsi'. Phillips, Janet. 2011. Asylum Seekers and Refugees: What are the facts? Sydney: Parliament of Australia. (2).

3 IOM Regional Office for The Middle East and North Africa. 2016. Migration to, from and in Middle East and North Africa Data Snapshot. (5) 


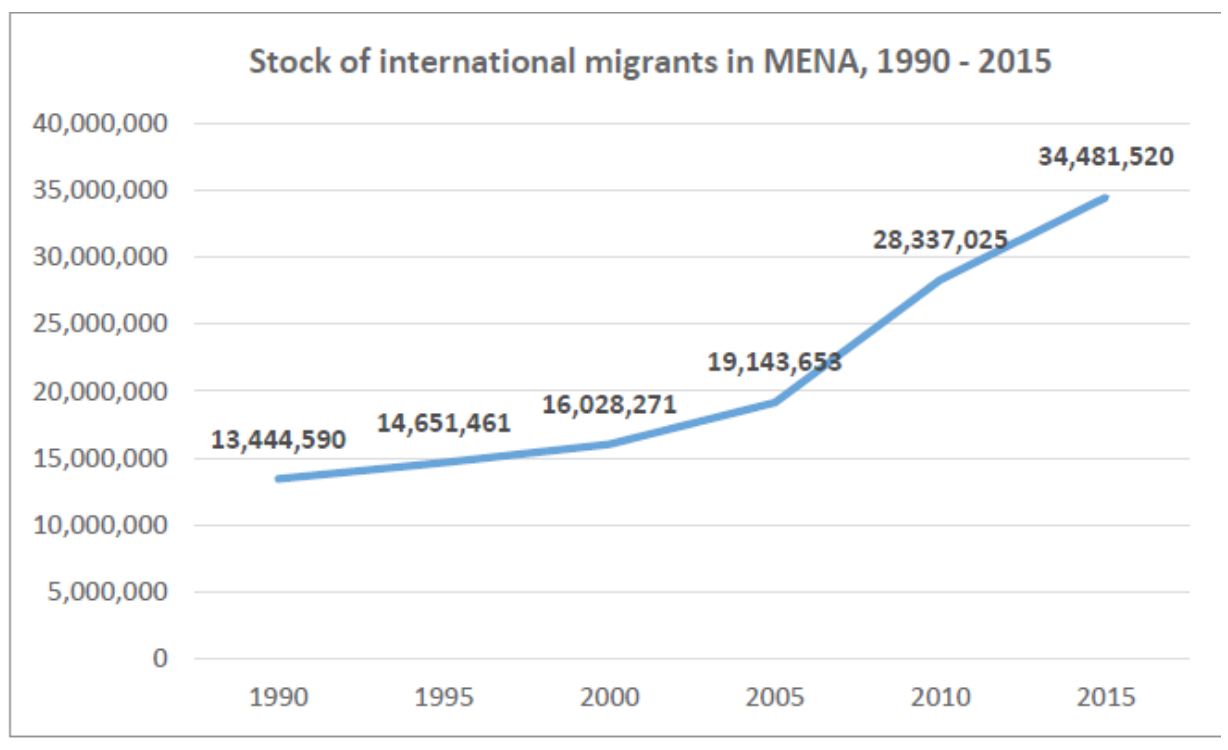

Sumber: International Organization for Migration

lipat dari jumlah migran pada tahun 1990 di saat terjadinya Perang Teluk antara Irak, Kuwait dan Arab Saudi. Melonjaknya jumlah migran ini merupakan akibat dari huru-hara yang terjadi di Timur Tengah yang prosesnya dimulai semenjak tahun 2003 ketika Amerika Serikat mulai menanamkan nilai-nilai liberalisme, terutama melalui jargon demokrasi, di kawasan tersebut. Seiring dengan proses internalisasi nilai-nilai tersebut, daratan Timur Tengah yang pada awalnya dipimpin oleh pemimpin-pemimpin otoriter berubah menjadi medan perang ${ }^{4}$. Hal ini disebabkan oleh benturan antara nilai-nilai demokrasi yang dipaksakan dan otoritarianisme yang sudah mengakar selama berpuluhpuluh tahun di Timur Tengah. ${ }^{5}$

Internalisasi nilai-nilai liberalisme tersebut mendorong terjadinya fenomena Arab Spring yang dimulai pada tahun $2011 .{ }^{6}$ Dimulai dengan aksiaksi demonstrasi di Tunisia menyusul tewasnya seorang penjual buah yang frustasi, Mohammed Bouazizi, yang berujung pada larinya Presiden Zine el Abidine Ben Ali ke Arab Saudi pada Januari 2011, aksi-aksi demo menentang

$4 \quad$ Perlini, Caterina. 2015. Democracy in the Middle East: External Strategies and Domestic Politics, (International Relations Insight and Analysis Report No. 10, 2015). (32)

5 Magen, Amichai. 2013. The Crisis of Governance in the Middle East: Implications for Democracy. Development \& Security. Jerusalem: Konrad-Adenauer-Stiftung Israel. (31) Ibid. 
pemerintah muncul di berbagai negara di Timur Tengah. Di beberapa negara, telah terjadi proses peralihan kekuasaan, seperti Tunisia dan Mesir.

Namun hingga saat ini, sudah lebih dari enam tahun pasca Arab Spring, di beberapa negara masih terjadi konflik berdarah. Libya, aksi-aksi demo disusul dengan serangan NATO yang menghancurkan berbagai infrastruktur dan setelah tergulingnya Qaddafi, negara itu menjadi ajang perang sipil dari berbagai faksi. Libya merupakan kasus menarik, mengingat komunitas internasional berperan dalam upaya penggulingan rezim Qaddafi. Pada Maret 2011, Dewan Keamanan PBB telah mengizinkan NATO untuk mengambil langkah yang diperlukan atas dasar Responsibility to Protect (R2P) dimana setiap negara yang ada di dunia tidak boleh mendiamkan suatu konflik yang mengancam HAM dengan nyata. ${ }^{7}$

Sementara itu, di Suriah, meski telah enam tahun terjadi perang antara pemerintah melawan kelompok-kelompok pemberontak, Dewan Keamanan PBB belum mengeluarkan resolusi didasarkan atas R2P tersebut. Saat ini di Suriah tengah terjadi perang yang berlarut-larut antara kelompokkelompok 'jihad' seperti Jabhah Al Nusra, Ahrar al Sham, dan Islamic State of Iraq and Syria (ISIS). ${ }^{8}$ ISIS bahkan kini telah menjadi teroris global yang dikutuk oleh komunitas internasional. Dikarenakan perang yang didalangi oleh ISIS, pengungsi berkewarganegaraan Suriah menjadi pengungsi yang paling banyak dalam catatan IOM hingga tahun 2015. Pada tahun 2010, pengungsi asal Suriah hanya berjumlah 20.000 orang saja. Namun, karena konflik bersenjata yang berkepanjangan ini, angka tersebut secara signifikan melonjak pada angka 4,9 juta pengungsi. Di sisi lain, negara-negara Timur Tengah yang juga banyak menyumbang untuk angka pengungsi adalah Afganistan (2,7 juta), Sudan (630 ribu), Irak (264 ribu) serta Yaman (178 ribu). ${ }^{9}$

Di balik besarnya tragedi kemanusiaan akibat perang di Timur Tengah, ada faktor bisnis yang sangat besar. Data menunjukkan bahwa hanya dalam

$7 \quad$ Zifcak, Spencer. 2012. "The responsibility to protect after Libya and Syria". Melbourne Journal of International Law. Vol.13 No. 1: 1.

8 Lia, Brynjar. 2016. Jihadism in the Arab World after 2011: Explaining Its Expansion. Oslo: Department of Culture Studies and Oriental Language University of Oslo. (3)

9 United Nations High Commissioner for Refugees. 2017. Facts and Figures about Refugees. Melalui <http://www.unhcr.ie/about-unhcr/facts-and-figures-about-refugees> [6/52017] 
setahun pertama era Arab Spring (2011-2012), ekspor senjata dari Uni Eropa meningkat $22 \% .^{10}$ Sementara itu, AS adalah negara pengekspor senjata terbesar ke Timur Tengah. Selain menjual langsung, AS juga memberikan dana bantuan (pinjaman atau hibah) kepada negara-negara agar mereka bisa membeli senjata produksinya. Ada tiga negara yang mendapatkan bantuan militer AS terbesar, yaitu Israel (3,1 miliar USD), Mesir (1,3 miliar USD), dan Yordania (350 juta USD). ${ }^{11}$

Artikel ini bertujuan menjawab pertanyaan mendasar atas fenomena konflik bersenjata yang terjadi di Timur Tengah, yaitu mengapa konflik bersenjata di Timur Tengah berkepanjangan? Penulis akan menggunakan menggunakan perspektif neoliberalisme dimana pasar global merupakan penguasa yang dapat memberikan perintah terhadap suatu negara. Menurut para ekonom Freiburg, dalam paham ekonomi neoliberal, negara bertugas untuk untuk melakukan deregulasi peraturan-peraturan yang mengancam kepentingan dari pemilik modal. ${ }^{12}$ Dalam kasus ini, perang merupakan suatu bisnis yang sangat menjanjikan bagi para produsen senjata. Oleh karena itu, keberlangsungan perang di Timur Tengah memang merupakan suatu kondisi yang dikehendaki oleh para produsen senjata karena mendapat keuntungan dari pembelian senjata yang mereka produksi. ${ }^{13}$ Dan salah satu aktor utama dalam jual beli senjata di Timur Tengah adalah American Military Industrial Complex.

\section{Landasan Teori}

Pembahasan mengenai konsep serta sejarah lahirnya neoliberalisme sangat diperlukan untuk memahami situasi perekonomian internasional.

10 Vredesactie. 2014. «European arms exports to Middle East reach record high in aftermath of Arab Spring». Melalui < https://www.vredesactie.be/en/nieuws/european-armsexports-middle-east-reach-record-high-in-aftermath-arab-spring $>$ [1/6/2017]

11 CNN. 2016. «Heress who buys the most weapons from the U.S.». Melalui <http://edition. cnn.com/2016/05/24/politics/us-arms-sales-worldwide/>. [2/5/2017]

12 Boas, Taylor C. dan Jordan Gans-Morse. 2009.“Neoliberalism: From New Liberal Philosophy to Anti-Liberal Slogan". Studies in Comparative International Development. Vol. 44 No. 2: 137-161

13 Petras, James. 2014. "The Soaring Profits of The Military-Industrial Complex, The Soaring Costs of Military Causalties". Melalui <http://www.globalresearch.ca/the-soaring-profits-

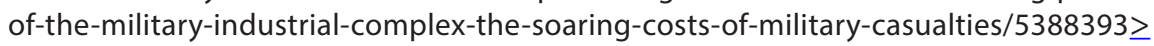
[3/32017] 
Pada masa sebelum Perang Dunia I, paham liberalisme klasik merupakan paham yang mendominasi corak ekonomi internasional ${ }^{14}$. Paham yang dipopulerkan oleh Adam Smith ini merupakan paham yang menyarankan bahwa negara tidak seharusnya ikut campur dalam suatu pasar. Hal ini didasari oleh kepercayaan bahwasanya pasar memiliki invisible hand yang dapat melalukan self-regulation. Oleh karena itu, aliran liberalisme klasik percaya bahwa pasar seharusnya dibebaskan dari merkantilisme negara guna memperoleh keuntungan yang maksimal sehingga sistem perekonomiaannya tidak bersifat zero-sum game, sebaliknya setiap negara akan memperoleh keuntungan (positive sum-game)..$^{15}$

Namun, praktik dari konsep ini menghadapi kegagalan pada tahun 1930-an di mana pasca Perang Dunia I, ekonomi negara-negara di dunia tidak kunjung membaik. Oleh karena itu, ekonom asal Inggris, John Maynard Keynes, melalui bukunya yang berjudul General Theory of Employment, Interest, and Money (1936) menyarankan bahwa pasar tidak seharusnya dibiarkan bebas begitu saja. Pemerintah juga patut melakukan intervensi dalam kehidupan ekonomi suatu negara guna memberikan kepastian dalam aspek kesejahteraan untuk rakyatnya. ${ }^{16}$ Pandangan Keynes ini sering diistilahkan dalam ilmu ekonomi-politik sebagai aliran Keynesian atau liberalisme neoklasik. $^{17}$

Seperti halnya liberalisme klasik, liberalisme neo-klasik juga menghadapi kebuntuan yang sama. Pada tahun 1970-an, banyak negara dalam tingkat global mengalami kemandekan ekonomi. ${ }^{18} \mathrm{Hal}$ ini mendorong para ekonom untuk memikirkan ulang konsep ekonomi internasional yang mampu menuntun ekonnomi global ke arah yang lebih baik dan menguntungkan. Alhasil, neoliberalisme lahir atas keprihatinan terhadap kegagalan dua pandangan ekonomi terdahulu dalam menjaga kestabilan perekonomian

14 Helleiner, Eric. 2003. "Economic Liberalism and Its Critics: The Past as Prologue?". Review of International Political Economy. Vol. 10 No. 4: 686

15 Marie-Slaughter, Anne. 1995. "International Law in a World of Liberal States". European Journal of International Law: 538.

16 Gilpin, Robert. 2001. Global Political Economy: Understanding The International Economic Order. Princeton: Pricenton University Press. (250)

17 Ibid (46)

18 Ibid (235) 
global, liberalisme klasik di tahun 1930-an dan liberalisme neo-klasik di tahun 1970-an. ${ }^{19}$

Neoliberalisme sendiri merupakan pemikiran yang didasari dari prinsipprinsip liberalisme klasik di mana pasar seharusnya dibebaskan dari intervensi pemerintah, atau dalam istilah latin adalah laissez-faire. ${ }^{20}$ Terminologi 'neo' dalam neoliberalisme menunjukkan bahwa liberalisme kini lahir dengan bentuk baru yang menyarankan agar peran pemerintah dibatasi hanya untuk melayani kepentingan pasar. Menurut pandangan ini, pemerintah seharusnya melakukan kebijakan-kebijakan yang pro terhadap kepentingan pasar seperti deregulasi, membuat rezim free trade dengan negara lain, dan privatisasi. ${ }^{21}$ Pandangan ini digunakan dalam menjalankan roda ekonomi global semenjak tahun 1970-an hingga saat ini. Yang harus dicermati dalam bagian ini adalah ekonomi-politik internasional, di bawah komando neoliberalisme, kini berada di bawah arahan pasar yang memiliki segudang modal untuk memaksa pemerintahan internasional dalam membentuk suatu kebijakan yang menguntungkan para pemilik modal. ${ }^{22}$

Dengan memahami kaitan sistem perekonomian dunia dengan konflik di Timur Tengah, penulis menggunakan konsep Military-Industrial Complex (MIC). Konsep ini berguna dalam menjelaskan fenomena berlarut-larutnya konflik bersenjata yang terjadi di Timur Tengah karena terdapat hubungan saling menguntungkan antara pemerintah Amerika Serikat dan perusahaanperusahaan produsen senjata yang berasal dari Amerika Serikat. Konsep MIC sendiri pada awalnya dipopulerkan oleh Mantan Presiden Amerika Serikat, Dwight Eisenhower yang juga merupakan mantan personel militer. Pada pidato perpisahannya sebagai Presiden Amerika Serikat di tahun 1961, Eisenhower mengingatkan bangsa Amerika Serikat bahwasanya pemerintah

19 Kotz, David M. 2000. “Globalization and Neoliberalism". Rethinking Marxism. Vol. 12 No. 2 (64)

20 Kapeller, Jakob dan Stephan Puhringer. 2010.“Democracy in Liberalism and Neoliberalism: The Case of Popper and Hayek". ICAE Working Paper Series. No. 10: 3

21 Springer, Simon, et all. 2016. The Handbook of Neoliberalism. New York: Routledge: 2016. (2)

22 Kabir, Abe de Jong Rezaul dan Thuy Tu Nguyen. 2007. "Capital Structure around the World: The roles of Firm-and Country-Specific Determinant". ERIM Report Series Research in Management: 24 
harus waspada terhadap pengaruh dari luar yang tidak berdasar, baik yang diupayakan maupun tidak, yaitu dari military-industrial complex. ${ }^{23}$

MIC adalah konsep yang menunjukkan bahwa terdapat kerjasama informal antara pemerintahan dari suatu negara dengan korporasi yang memproduksi senjata-senjata yang digunakan untuk berperang. ${ }^{24}$ Fenomena ini sangat dimungkinkan untuk terjadi karena kedua belah pihak, baik pemerintah maupun korporasi mendapatkan untung dari adanya kegiatan ekonomi di bidang persenjataan ini. Korporasi produsen senjata mendapatkan untung dari penjualan senjata-senjata di negara-negara yang tengah berada dalam konflik bersenjata. Di sisi lain, negara juga mendapatkan untung dari pajak yang akan ia peroleh dari penjualan senjata tersebut. Kerjasama antar dua pihak ini merupakan suatu simbiosis mutualisme. Oleh karena itu, pihak produsen senjata meminta atau mengarahkan negara untuk membuat kebijakan yang secara langsung maupun tidak langsung mendukung keberlangsungan suatu perang. Fenomena tersebut lebih dikenal dengan istilah corporate-driven policies.

\section{Metodologi Penelitian}

Artikel ini akan membahas keterkaitan antara ekonomi-pasar (neolib) dengan keberlanjutan perang melalui analisis data yang menunjukkan tren ekspor senjata dari negara-negara produsen senjata yang menjadi penyuplai utama persenjataan di wilayah Timur Tengah. Lebih jauh lagi, pendataan perusahaan-perusahaan yang meraup untung dalam konflik ini juga diperlukan. Data-data tersebut merupakan variabel pertama dalam penelitian ini yang menunjukkan siapa yang berkepentingan yang memiliki kepentingan ekonomi dalam konflik ini. Variabel berikutnya adalah kebijakan luar negeri negara yang ditunjukkan oleh analisis dari variabel pertama terkait dengan konflik bersenjata di Timur Tengah. Hubungan antar kedua variabel akan menunjukkan bagaimana negara, dalam dunia yang menganut neoliberalisme, dikuasasi oleh pasar. Sehingga, kebijakan yang dikeluarkan oleh negara-negara adidaya bersifat corporate-driven policies.

23 Dunne, J Paul dan Elisabeth Skons. 2009. "The Military Industrial Complex". Melalui <arecon.org.uk/DPs/0907.pdf> [10/4/2017]

24 Mehta, Vijay. 2012. The Economies of Killing: How The West Fuels War and Poverty in the Developing World. London: Pluto Press. (40) 
Paradigma yang digunakan dalam menjawab rumusan masalah penelitian ini adalah paradigma ekonomi neoliberalisme yang berpendapat bahwasanya ekonomi-politik internasional saat ini bersifat corporatedrivenpolicies di mana segala kebijakan negara didasarkan pada kepentingan ekonomi suatu perusahaan, dalam kasus ini adalah perusahaan-perusahaan yang memproduksi senjata. Atas dasar paradigma tersebut, artikel ini memiliki hipotesis bahwasanya keberlangsungan konflik di kawasan Timur tengah merupakan kehendak dari kaum pemilik modal yang menginginkan profit dari penjualan senjata yang dipergunakan untuk perang di kawasan tersebut.

Sistematika pembahasan dalam artikel ini diawali dengan sejarah konflik bersenjata yang terjadi di Timur Tengah. Pembahasan tersebut diperlukan untuk memahami peta politik di kawasan Timur Tengah. Hal berikutnya yang akan dibahas adalah perkembangan industri persenjataan. Pembahasan ini memliki urgensi yang sangat tinggi, mengingat senjata sebagai komoditas memiliki perbedaan mendasar dalam pemasarannya jika dibandingkan dengan komoditas lainnya. Pada akhirnya, artikel ini menjawab pertanyaan apa yang menyebabkan konflik bersenjata di Timur Tengah berkepanjangan melalui aplikasi konsep military-industrial Complex. Konsep tersebut dapat menjelaskan bagaimana pemerintahan suatu negara bekerjasama dengan produsen senjata secara saling menguntungkan, sehingga berakhirnya konflik bersenjata di Timur Tengah merupakan suatu hal yang tidak diinginkan. Oleh karena itu, data terakhir yang menunjukkan akan adanya military-industrial complex adalah keuntungan yang dapat diperoleh negara atas berlangsungnya konflik di Timur Tengah.

\section{Sejarah Konflik Timur Tengah}

Menurut Noam Chomsky, kawasan Timur Tengah merupakan kawasan yang sering mengalami konfik bersenjata dari masa ke masa. ${ }^{25}$ Perang IsraelPalestina yang sudah berlangsung semenjak tahun 1947, Perang Teluk yang terjadi pada tahun 1990, Perang sipil di Yaman pada tahun 1994, Perang Irak pada tahun 2003, dan serangkaian perang sipil yang terjadi akhir-akhir ini seperti di Suriah, Irak, dan Yaman merupakan bukti nyata bahwa daratan Timur

25 The Editorial Board. 2006. "Politics and Conflict in Middle East". Development Issues. Vol. 8 No. 2: 2 
Tengah merupakan daratan yang tak pernah sepi dari perang dan perebutan kekuasaan. Perang yang terjadi bisa berupa perang sipil (antara warga melawan pemerintah, atau penjajah, dalam kasus Israel), bisa pula berupa serangan langsung tentara AS dan koalisinya pada kasus Perang Teluk tahun 1990, Perang Irak tahun 2003, dan Perang Libya tahun 2011. Dalam retorika para pemimpin Amerikat Serikat, perang Irak 2003 merupakan'perang suci' di mana mereka berperang demi kebebasan manusia, khususnya rakyat Irak serta perang melawan terorisme (war on terrorism) yang mengancam keamanan warga Amerika Serikat (atas dasar klaim intelijen AS bahwa Saddam memiliki senjata pembunuh massal). ${ }^{26}$ Perang tersebut membawa hasil tergulingnya salah satu rezim otoriter di Timur Tengah, Saddam Husein, meski kemudian di tahun 2011 terungkap bahwa keberadaan senjata pembunuh massal itu tidak terbukti. ${ }^{27}$

Keruntuhan rezim Saddam dipandang sebagai tonggak sejarah demokrasi pertama khususnya di Irak dan Timur Tengah pada umumnya. Al-Marashi berpendapat bahwa penanaman demokrasi di Irak merupakan langkah awal Amerika Serikat untuk menanamkan nilai-nilai demokrasi-liberal di kawasan Timur Tengah. ${ }^{28}$ Menyusul tumbangnya Saddam, dibentuklah pemerintahan baru yang dipilih melalui pemilu dan berbagai langkah demokrasi lainnya. AS kemudian melakukan berbagai upaya penyebaran demokrasi melalui dukungan kepada lembaga-lembaga sipil di berbagai negara Timur Tengah. Lembaga-lembaga yang berperan dalam proyek ini antara lain The National Endowment for Democracy (NED), The National Democratic Institute for International Affairs (NDI), dan The United States Agency for International Development (USAID) .

Sebagai hasilnya, Arab Spring mulai bergejolak di tahun 2011, dimana kaum muda di berbagai negara Timur Tengah bangkit berdemonstrasi menentang pemerintah negara-negara mereka dan menuntut demokratisasi. Aksi demo pertama muncul di Tunisia yang berhasil melengserkan rezim

26 Lieberfeld, Daniel. 2005. "Theories of Conflict and The Iraq War". International Journal of Peace Studies. Vol. 10, No. 2: 2

27 Telegraph. 2013. «Iraq war: the greatest intelligence failure in living memory». Melalui <http://www.telegraph.co.uk/news/worldnews/middleeast/iraq/9937516/lraq-war-thegreatest-intelligence-failure-in-living-memory.html> [2/3/2017

28 Bouado, Nana Adu-Pipim. 2012. "Invasion of Iraq: Instrospective Analysis of US Long Term Policies in the Middle East". Journal of Political Studies. Vol. 19 No. 2: 88 
Zine El Abidine Bin Ali yang sudah berkuasa selama 23 tahun. Aksi ini dipicu oleh aksi bakar diri Mohamed Bouazizi untuk menunjukkan kekecewaannya pada pemerintahan otoriter yang korup. Kejadian di Tunisia memicu aksiaksi demoa di kawasan Timur Tengah lainnya untuk bersegera melakukan revolusi. ${ }^{29}$

Efek spillover transisi politik di Arab ini sering dikenal dengan istilah Musim Semi Arab atau Kebangkitan Arab (Arab Spring). Negara-negara yang terkena dampak oleh Arab Spring adalah Libya, Aljazair, Yordania, Sudan, Oman, Arab Saudi, Mesir, Maroko, Yaman, Irak, Kuwait, dan Suriah. Perubahan situasi politik domestik secara masif ini berlangsung secara cepat dan serentak yang membuat sebagian negara mengalami revolusi politik, perang saudara, serta kerusuhan sipil. ${ }^{30}$ Untuk lebih detailnya, kita dapat melihat pemetaan transisi politik beserta dampaknya melalui peta di bawah ini.

\section{Gambar2. Peta Kericuhan Akibat Arab Springs}

Di beberapa negara, terutama Libya, Suriah, Yaman, dan Irak, proses Arab Spring memunculkan konflik bersenjata yang tak kunjung usai. Selain kerugian

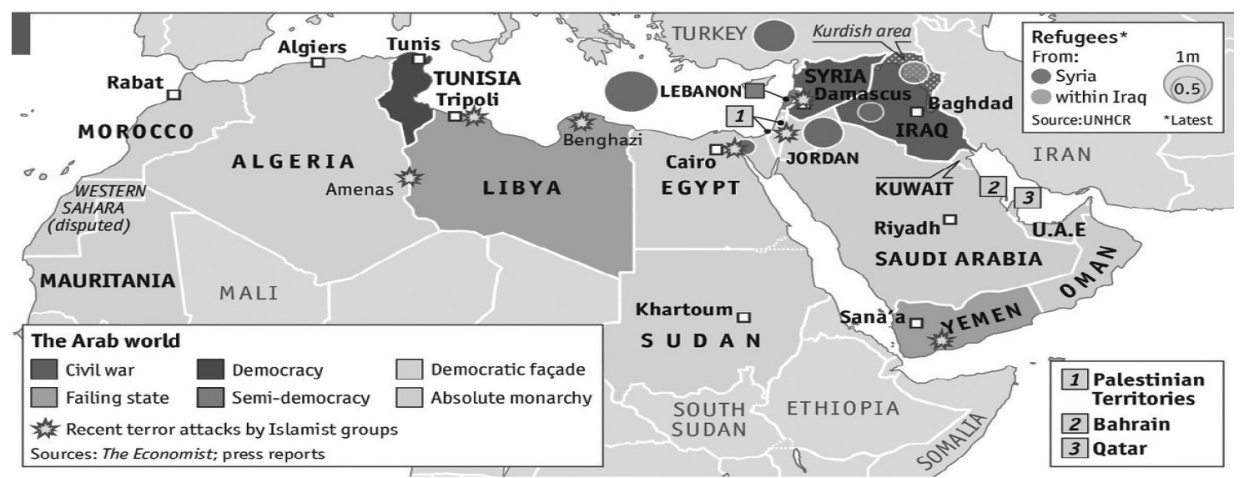

Sumber:The Economist

29 Abouzeid, Reina. 2011. "Bouazizi: The Man Who Set Himself and Tunisia on Fire". Melalui <http://content.time.com/time/magazine/article/0,9171,2044723,00.html $\geq$ [12/2/2017]

30 Gocer, Sertan Cinardan Ismet. 2014. "The Reasons and Economic and Political Consequences of Arab Springs". Khazar Journal of Humanities and Social Science. Vol. 17 No. 2: 39-49 
yang diderita masyarakat sipil (gelombang pengungsian) yang telah dibahas sebelumnya, terjadi pula kerugian ekonomi. Menurut World Bank, kerugian ekonomi yang dialami oleh negara-negara yang berkonflik mencapai angka 35 miliar dolar karena uang tersebut dibelanjakan untuk berperang. ${ }^{31}$ Walaupun kerugian-kerugian tersebut terus meningkat, komunitas internasional tidak mengambil langkah konkret yang dapat menghentikan kekacauan ini.

Negara yang paling banyak melibatkan diri di tengah pusaran konflik Timur Tengah adalah Amerika Serikat, mulai dari Irak, Libya, Suriah, Afganistan, Pakistan, Israel, Palestina, dan Iran. Greg Myre berpendapat bahwa Amerika Serikat telah banyak melakukan intervensi militer di kawasan Timur Tengah namun intervensi-intervensi tersebut justru gagal membawa perdamaian. ${ }^{32}$

\section{Industri Persenjataan dan Negara}

Senjata merupakan peralatan perang yang paling penting. Pada awalnya, senjata diproduksi oleh pemerintahan suatu negara sendiri. Hal ini dilakukan negara karena negara perlu melindungi dirinya dari ancaman negara lainnya. Namun pada abad ke-18, seiring dengan perkembangan nilai-nilai liberalisme yang menyarankan bahwa negara harusnya tidak turut campur dalam kegiatan ekonomi, produksi persenjataan yang pada awalnya di bawah komando pemerintahan diserahkan pada sektor privat. ${ }^{33} \mathrm{Hal}$ ini dilakukan demi meningkatkan perkembangan teknologi dari senjata yang akan digunakan untuk berperang. Melalui ini, persenjataan untuk berperang menjadi komoditas dalam pasar global.

Berbeda dengan komoditas lainnya, bisnis persenjataan merupakan bisnis yang memiliki pola ekonomi tersendiri. Pada umumnya, setiap produsen dalam memproduksi suatu komoditas pasti menginginkan suatu profit dalam kegiatan ekonominya. Hal yang sama juga terjadi pada industri persenjataan ini. Produsen senjata-senjata perang memproduksi dan mengembangkan

31 Daragahi, Borzou. 2014."War has cost MiddleEast \$35bn, saysWorld Bank”. Melalui <https:// www.ft.com/content/f600d7b6-86d1-11e4-8a51-00144feabdc0 $>$ [19/12/2016]

32 Myre, Greg. 2014. "America's Middle East Scorecard: Many Interventions, Few Successes". Melalui <http://www.npr.org/sections/parallels/2014/08/25/341892606/america-smiddle-east-scorecard-many-interventions-few-successes> [2/4/2017]

33 Perlo-Freeman, Sam dan Elisabeth Skons. 2008. "The Private Military Service Industry" SIPRI Insights on Peace and Security, No. 2008/1: 2. 
persenjataan dengan harapan untuk mendapatkan keuntungan sebanyakbanyaknya. Konsekuensi yang muncul jika produksi senjata telah dilakukan adalah menjualnya. Agar dapat menjual senjata-senjata tersebut, pihak korporasi penyuplai senjata mendorong pemerintahan suatu negara untuk membeli persenjataan tersebut.

Jika negara tidak sedang berada dalam konflik bersenjata, otomatis persenjataan tersebut tidak akan berguna. Oleh karena itu, perusahaanperusahaan senjata yang memiliki modal yang tidak sedikit ini mendorong negara untuk memulai suatu konflik bersenjata yang dapat menguntungkan pihak korporasi produsen senjata ${ }^{34}$. Sebenarnya, tidak hanya korporasi yang diuntungkan dengan adanya kebijakan untuk berperang tersebut, negara juga memperoleh keuntungan yang berupa pajak yang tidak sedikit dari pihak korporasi. Keuntungan lain yang didapat oleh negara adalah melonjaknya investasi terhadap perusahaan-perusahaan yang bergerak dalam industri pertahanan ini. ${ }^{35}$

Fenomena saling menguntungkan tersebut diistilahkan oleh Dwight Eisenhower sebagai Military-Industrial Complex dimana korporasi memiliki kepentingan untuk menjual persenjataan hasil produksi dan negara membuat kebijakan yang dapat menguntungkan korporasi tersebut. ${ }^{36} \mathrm{Hal}$ ini sesuai dengan hukum yang dikemukakan oleh paham neoliberalisme di mana negara membuat kebijakan yang bersifat corporate-policies driven.

\section{Military-Industrial Complex: Kaitan Neoliberalisme dan Konflik Bersenjata di Timur Tengah}

Semenjak tahun 1970, alur pedagangan senjata berpusat pada negaranegara yang sedang berkembang karena negara-negara tersebut hendak melindungi dirinya dan potensi sumber daya alamnya dari ancaman pihak asing. Kawasan Timur Tengah yang didominasi oleh negara-negara bekembang juga melakukan proses militerisasi seperti halnya negara-negara

34 Dunlap Jr., Charles J. 2011. "The Military-Industrial Complex". The Modern American Military. Vol. 140 No. 3: 136

35 Kone, Amimata M. 2013. “The Military-Industrial Complex in the United States: Evolution and Expansion from World War II to War on Terror". Inquiries Journal, Vol. 5 No. 8

36 Eisenhower, Dwight D. 1987. "The Military-Industrial Complex". The American Journal of Economics and Sociology. Vol. 46 No. 2: 150 
berkembang lainnya. Menurut Joe Stork dan James Paul, semenjak tahun 1972 hingga 1982, personil militer di kawasan Timur Tengah naik hingga 64 persen dari 2,1 juta orang menjadi 3,5 juta orang. Pada periode yang sama, angka unit tempur utama di kawasan timur tengah tumbuh hingga 140 persen dari angka 11.250 menjadi 27.000 yang diperkirakan melebihi angka unit tempur Amerika Serikat dan NATO. ${ }^{37}$

Dalam kurun waktu tersebut, terdapat satu nama yang muncul sebagai pedagang senjata terkaya yang berasal dari Timur Tengah, yaitu Adnan Khassogi. Pada awal tahun 1980-an, dia mampu meraih keuntungan hingga 4 miliar dollar dari bisnis perdagangan senjata dengan pemerintah dan aktor swasta. Namun, pada akhir tahun 1980-an, bisnis yang dijalankan olehnya mengalami kebangkrutan karena gaya hidupnya yang cenderung berfoyafoya dan saran-saran buruk dari konsultan bisnisnya. Karena hal tersebut, Adnan Khassogi dililit hutang sebesar 21 juta dollar Amerika..$^{38} \mathrm{Hal}$ ini membuat Khassogi kehilangan peran pentingnya sebagai pedagang senjata yang penting di kawasan Timur Tengah. Dalam kasus konflik bersenjata kontemporer di kawasan Timur Tengah, peran Khassogi pun hampir tidak ditemui karena perbedaan konteks perdagangan persenjataan di Timur Tengah.

DitengahelitpolitikAS, ada tokoh-tokohyang menjadipendukung perang, antara lain John McCain, senator asal Arizona yang pernah mencalonkan diri menjadi presiden AS pada pemilu tahun 2008. Saat berkampanye ia banyak didukung oleh produsen senjata, antara lain Dillon Aero yang menjadi penyuplai senjata untuk militer AS. Dalam pemungutan suara di parlemen, politisi seperti McCain berperan dalam keputusan perang atau penjualan senjata. Misalnya, pada September 2016, Senat AS memutuskan mendukung penjualan senjata dari AS ke Saudi senilai 1 Miliar USD, meskipun senjata itu digunakan untuk membombardir Yaman. Saat ini McCain menjabat sebagai Ketua Komite Armed Service di Senat AS. ${ }^{39}$

37 Stark, Joe dan James Paul. 1983. "Arm Sales and The Militarization of the Middle East". Middle East Research and Information Project. Vol. 13

38 The Economist. 2013.“Chasing Debtors: Cash-strapped Khashoggi?" Melalui <http:// www.economist.com/news/finance-and-economics/21578447-intriguing-twists-anddiscoveries-case-against-former-arms $>$ [24/2/2017] 
Sebagaimana yang telah dijelaskan oleh konsep MIC, negara akan cenderung untuk meningkatkan anggaran pertahanan untuk memenuhi kepentingan para korporat yang bergerak dalam industri militer. ${ }^{40}$ Sesuai dengan logika berpikir tersebut, Departemen Pertahanan Amerika Serikat meningkatkan anggaran belanja persenjataan untuk perang di Irak pada tahun 2003. Hal ini dapat dibuktikan dengan grafik anggaran militer Amerika Serikat di bawah ini.

\section{Gambar 3: Grafik Anggaran Pertahanan Amerika Serikat semenjak Perang Dunia II hingga sekarang}

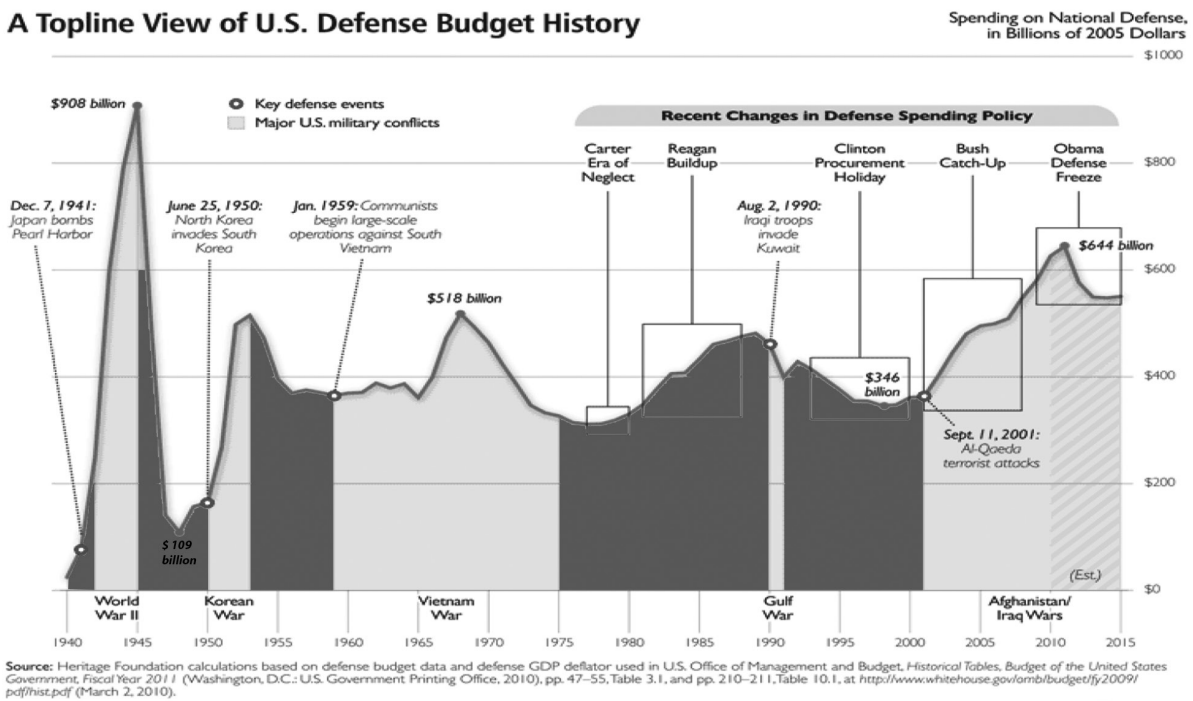

Sumber: heritage.org

Melalui grafik di atas, kita dapat melihat bahwasanya lonjakan anggaran pertahanan Amerika Serikat dimulai semenjak negara tersebut mendeklarasikan War on Terrorism pada tahun 2003. Bahkan pada tahun 2011 di mana Arab Spring bergulir, anggaran pertahanan Amerika Serikat hampir mencapai dua kali lipat dari anggarannya pada tahun 2003. Meningkatnya anggaran pertahanan Amerika Serikat dari tahun ke tahun dapat diindikasikan

sale-to-saudi-arabia.html> [14/3/2017]

Amimata M. Kone, loc. cit. 
bahwa Amerika Serikat terikat dengan military-industrial complex dan menjalin hubungan yang dekat dengan para pemilik modal yang bergerak dalam bisnis militer karena anggaran pertahanan Amerika pasti akan berujung pada industri militer.

Karena sifat dasar kapitalisme adalah selalu berupaya untuk mencari pasar yang baru, ${ }^{41}$ pemerintah Amerika Serikat beserta korporasi-korporasi yang bergerak dalam industri militer berencana untuk mencari pasar baru. Menurut Joe Stark dan James Paul, Timur Tengah merupakan wilayah baru yang tengah dijadikan wilayah pemasaran oleh korporasi. ${ }^{42}$ Pandangan ini dapat dibuktikan dengan mengaitkan tingkat ekspor persenjataan yang berasal dari Amerika Serikat yang tersedia pada tabel di bawah ini.

Tabel 1. Perjanjian Perdagangan Senjata berdasarkan Importer dan Eksporter

\begin{tabular}{|c|c|c|c|c|c|c|c|c|}
\hline & \multicolumn{2}{|c|}{ Asia } & \multicolumn{2}{|c|}{ Near East } & \multicolumn{2}{|c|}{ Latin America } & \multicolumn{2}{|c|}{ Africa } \\
\hline & 2004-2007 & $2008-2011$ & 2004-2007 & $2008-2011$ & 2004-2007 & $2008-2011$ & 2004-2007 & $2008-2011$ \\
\hline United States & 10,520 & 18,127 & 19,962 & 91,974 & 1.591 & 2,590 & 156 & 296 \\
\hline Russia & 20,900 & 16,300 & 16,300 & 6,000 & 4.100 & 7,800 & 400 & 1,400 \\
\hline France & 5,100 & 4,100 & 2,700 & 4,000 & 500 & 8,600 & 100 & 600 \\
\hline United Kingdom & 2,400 & 1,300 & 17,500 & 1,100 & 400 & 300 & 0 & 0 \\
\hline China & 3,800 & 4,000 & 2,600 & 1,500 & 400 & 800 & 1,300 & 1,500 \\
\hline Germany & 2,500 & 1,900 & 2,000 & 3.200 & 400 & 200 & 0 & 100 \\
\hline Italy & 1,200 & 2,100 & 900 & 2,700 & 100 & 900 & 200 & 100 \\
\hline All Other European & 4,200 & 5,800 & 2,800 & 5,600 & 3,000 & 2,200 & 600 & 1,000 \\
\hline All Others & 6,600 & 6,700 & 1,200 & 500 & 900 & 1.400 & 400 & 900 \\
\hline Major West Europeans & {$[11,200$} & 9,400 & 23,100 & 11,000 & 1.400 & 10,000 & 300 & $800]$ \\
\hline TOTAL & 57,220 & 60,327 & 65,962 & 116,574 & 11,391 & 24,790 & 3,156 & 5,896 \\
\hline
\end{tabular}

Sumber:Pemerintahan Amerika Serikat dalam Congressional Research Service

Tahun 2004 merupakan tahun yang tepat untuk melihat korelasi antara kebijakan 'war on terorism' dan kepentingan MIC karena pada tahun tersebut Amerika Serikat sudah berhasil menggulingkan rezim Sadam Husein di Irak dan mampu memulai proses internalisasi nilai-nilai demokrasi di kawasan tersebut. Berdasarkan tabel di atas, Amerika Serikat mendominasi ekspor persenjataan di kawasan Timur Tengah sejak tahun 2004 hingga 2011. Pada

41 Ritzer, George dan Nathan Jurgenson. 2010. “Production, Consumption and Prosumption: The Nature of Capitalism in the Age of the digital 'prosumer'". Journal of Consumer Culture. Vol. 10 No. 1: 23

42 Stark, Joe dan James Paul, 1983, Op. Cit. 
tahun 2004-2007, Amerika Serikat telah mengekspor persenjataan dengan total 19.962 juta USD. Angka tersebut melonjak berkali-kali lipat pada tiga tahun berikutnya. Angka ekspor persenjataan yang berasal dari Amerika Serikat mencapai 91.974 juta USD. Peningkatan angka tersebut merupakan konsekuensi atas eksistensi Arab Spring yang sudah mulai muncul pada tahun 2010.

Berdasarkan data yang telah diolah dari SIPRI, empat di antara lima perusahan terbesar yang bergerak dalam industri militer adalah perusahaan yang berada di Amerika Serikat. Empat perusahaan tersebut adalah Boeing, Lockheed Martin Corp., Northrop Gruman Corp., dan Raytheon. Pada tahun 2002 ketika President Bush belum mendeklarasikan War on Terrorism, semua perusahaan tersebut hanya meraup untung tidak lebih dari 500 juta dollar. Namun pada tahun berikutnya, keuntungan mereka mencapai kisaran 700 juta dollar. Seiring dengan berjalannya perang di kawasan Timur Tengah, keuntungan mereka melonjak berkali-kali lipat. Pada tahun 2015, Boeing berhasil meraup keuntungan sebesar 5.176 juta dollar, disusul oleh Lockheed Martin Corp. dengan 3.605 dollar, Raytheon dan Northtrop Grumman Corp. berada pada kisaran keuntungan sebesar 2.000 juta dollar. ${ }^{43}$ Angka-angka tersebut bukanlah angka yang sedikit. Oleh karena itu, walaupun perang merupakan suatu nestapa bagi para penduduk yang tinggal di medan perang tersebut namun hal tersebut merupakan suatu keuntungan yang melimpah bagi para produsen senjata.

Bukti lain bahwa Amerika Serikat beserta para produsen senjata merupakan aktor yang menghendaki keberlangsungan konflik bersenjata di Timur Tengah ini adalah kebijakan-kebijakan luar negeri yang berkaitan dengan konflik di Timur Tengah. Dalam konflik bersenjata di Timur Tengah, Amerika Serikat selalu membuat kebijakan luar negeri yang bersifat untuk memulai perang. Di antara kebijakan luar negeri yang diambil oleh Amerika Serikat adalah invasi Irak pada tahun 2003 yang berujung pada internalisasi nilai-nilai demokrasi-liberal yang kelak memicu Arab Spring, intervensi militer di Libya pada tahun 2011, intervensi militer di Suriah pada tahun 2011 hingga

43 SIPRI. 2015. “The SIPRI Top 100 arms-producing and military services companies in the world (excluding China) in 2015". Melalui <https://www.sipri.org/sites/default/files/SIPRITop-100-2002-2015.xlsx> [21/3/2017] 
saat ini, dan yang terakhir adalah sikap Amerika Serikat yang pro terhadap para pemberontak di Turki. ${ }^{44}$ Dari keempat kebijakan luar negeri tersebut, Amerika Serikat selalu berpihak kepada mereka yang membutuhkan senjata. Kenyataan ini menegaskan bahwasanya kebijakan luar negeri Amerika Serikat didasarkan atas kepentingan para produsen senjata yang dapat meraup untung jika aktor-aktor konflik membeli senjata yang diproduksinya. Oleh karena itu, dapat disimpulkan bahwa kebijakan luar negeri Amerika Serikat terhadap konflik di Timur Tengah bersifat corporate-driven policies.

Setelah membahas keuntungan yang didapatkan oleh para produsen senjata, hal berikutnya yang perlu dibahas adalah keuntungan Amerika Serikat sendiri. Harga saham Dow Jones U.S. Aerospace \& Defense (DWCARD) yang mewakili industri pertahanan di Amerika Serikat meningkat secara drastis semenjak tahun 2003, tahun ketika Presiden Bush mendeklarasikan War on Terrorism. ${ }^{45}$ Pada tahun 2003, indeks DWCARD hanya berada pada poin 2.000. Namun seiring dengan bergulirnya perang di Timur Tengah yang membuat produsen alat militer terus meraup keuntungan, poin DWCARD saat ini mencapai pada angka 13.918,46. Untuk lebih detail, kenaikan drastis poin saham tersebut dapat kita lihat melalui grafik di bawah ini.

\section{Gambar 4. Perkembangan indeks DWCARD sejak tahun 2002 hingga sekarang}

Naiknya harga saham DWCARD menunjukkan bahwa permintaan untuk berinvestasi pada bisnis ini sangat tinggi. Jika para pemilik modal yang lain berminat untuk berinvestasi dalam sektor ini maka keuntungan kapital akan diperoleh Amerika Serikat juga. Keuntungan ekonomi tersebut membuat Amerika Serikat untuk berusaha mempertahankan situasi huru-hara yang terjadi di Timur Tengah karena eksistensi perang merupakan fenomena yang dapat memberikan keuntungan ekonomi baik bagi pemerintahan Amerika Serikat itu sendiri dan para korporasi yang bergerak dalam industri militer.

\section{Kesimpulan}

$44 \quad$ Myre, Greg. op. cit.

45 Karlin, Mark. 2015. "US Weapons Industry Profits From Conflicts of Carnage in Middle East". Melalui <http://www.truth-out.org/buzzflash/commentary/us-weapons-industryprofits-from-conflicts-of-carnage-in-middle-east> [2/1/2017] 


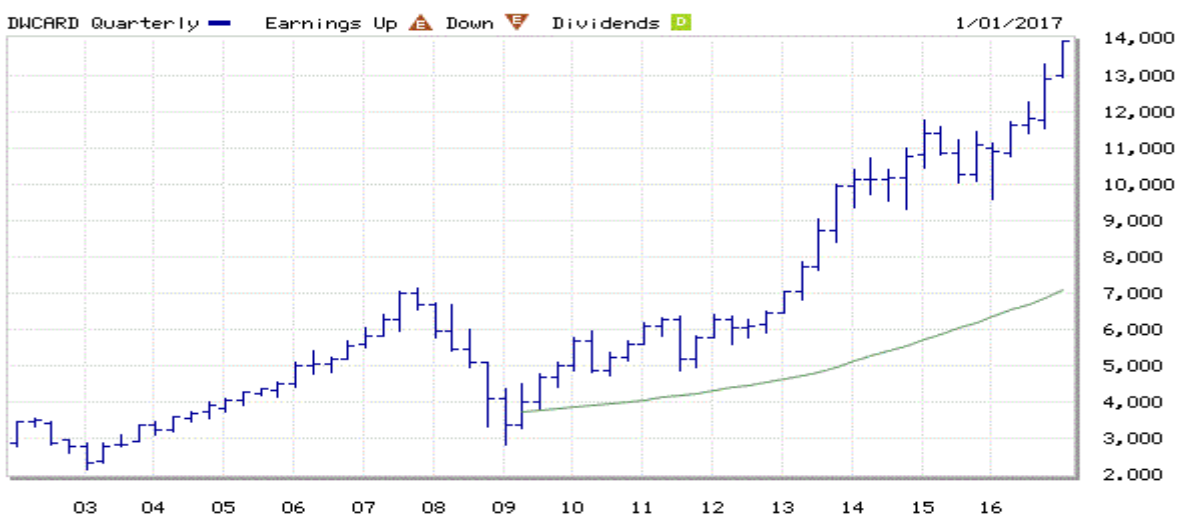

Sumber: Marketwatch.com

Dalam perekonomian yang bersifat neoliberal, negara akan patuh terhadap perintah para pemilik modal. Dalam kasus konflik bersenjata yang terjadi di TimurTengah, Amerika Serikat merupakan negara yang memutuskan kebijakan luar negerinya atas dasar kepentingan para produsen senjata. Hal ini dapat dijelaskan oleh konsep yang dipopulerkan oleh Eisenhower, yaitu military-industrial complex. Fenomena military-industrial complex ini terjadi di Amerika Serikat dan merupakan jawaban mengapa kebijakan luar negeri Amerika Serikat selalu berpihak kepada perang. Pemerintah AS dan korporasi senjata berkepentingan agar kegiatan ekonomi di sektor ini dapat terus bertahan dan mendapatkan peningkatan profit. Timur Tengah merupakan wilayah dimana korporasi-korporasi Amerika Serikat meraih profit besar dalam bisnis ini. Oleh karena itulah, mereka amat berkepentingan agar konflik bersenjata di Timur Tengah terus berlangsung dalam kurun waktu yang lama. Bagaimanapun, penulis tidak menutup mata terhadap faktor-faktor lain yang mempengaruhi keberlangsungan konflik bersenjata di Timur Tengah, seperti pertarungan hegemonik-ideologis antara Amerika Serikat dan Rusia. Namun pandangan alternatif mengenai American Military-Industrial Complex yang penulis sajikan sebagai faktor dalam keberlangsungan konflik bersenjata di Timur Tengah merupakan faktor yang signifikan dan patut dipertimbangkan. 
